\title{
Adsorptive Removal of Remazol Brilliant Violet-5R Dye from Aqueous Solutions using Calcined Eggshell as Biosorbent
}

\author{
Eszter Rápó, ${ }^{1,2}$ Katalin Posta, ${ }^{2}$ Maria Suciu, ${ }^{3}$ Robert Szép ${ }^{4}$ \\ and Szende Tonk ${ }^{1, *}$ \\ ${ }^{1}$ Environmental Science Department, Sapientia Hungarian University of Transylvania, \\ Calea Turzii 4, 400193 Cluj-Napoca, RO \\ ${ }^{2}$ Plant Protection Institute, Szent István University, Páter K. 1, H-2100 Gödöllő, HU \\ ${ }^{3}$ National Institute for Research and Development of Isotopic and Molecular Technologies, Electron Microscopy Integrated \\ Laboratory, Donath 67-103, 400293 Cluj-Napoca, RO \\ ${ }^{4}$ Faculty of Economics, Sapientia Hungarian University of Transylvania, Piața Libertății 1, 530104 Miercurea-Ciuc, RO* \\ Corresponding author: E-mail: tonk.szende@sapientia.ro
}

Received: 02-25-2019

\begin{abstract}
As a result of industrial development water pollution has become a major issue. Providing clean water of sufficient quality and quantity is essential. According to literature, 100000 different dyes are used worldwide in the printing, food and textile industries. Remazol Brilliant Violet-5R belongs to the group of azo dyes used in the textile industry. The purpose of this paper is to study the removal of anionic dye RBV-5R using calcined eggshell. We investigated the effect of initial dye concentration (20-100 mg/L RBV-5R), biomass amount, contact time, temperature, and $\mathrm{pH}$ on the adsorption process. We calculated the amounts of adsorbed material in equilibrium and the efficiency of the adsorption process. Various studies were performed on the adsorption process and the adsorbent morphology (EDX, SEM, FTIR, Raman), as well as isotherm (Langmuir, Freundlich, Temkin and Dubinin-Radushkevich), kinetic and diffusion models were used to characterize the process. Calcined eggshell was also characterized by thermogravimetric, BET surface methods. Based on the results obtained, it can be said that the calcined eggshell can be used effectively to remove the dye from the aqueous solution.
\end{abstract}

Keywords: Adsorption; calcined eggshell; Remazol Brilliant Violet-5R

\section{Introduction}

Water is the source of life, our existence, and our civilization depends to a great extent on the presence of good quality water. ${ }^{1}$ Today, about 232 million inhabitants in 26 countries live in water scarcity, mainly in the African and Middle Eastern countries, but also in the Netherlands, Belgium and Hungary. ${ }^{2,3}$ Several cities around the world are struggling with water crisis. For instance, the population of Cape Town can use 50 liters of water per day. A similar albeit somewhat less urgent problem faces Mexico and Melbourne as well. According to an article in The New York Times, Jakarta has become so dry that the city is sinking due to the extraction of the huge amount of groundwa- ter. In Brazil's most populous city (São Paulo), water was pumped out of sludge in 2015, since it was enough only for 20 days for the population. ${ }^{4-6}$ Humanity has used materials since ancient times that are capable of staining other materials, initially working with natural colors of animal and vegetable origin. Modern industries, however, use synthetic dyes instead. Remazol Brilliant Violet-5R (Table 1 ), one of the most important dyes in the textile industry, is an organic dye that can be classified as reactive dye, as well as azo dye. Reactive dyes are typically anionic in nature, highly soluble in water, and resistant to light. ${ }^{7} \mathrm{RBV}$ $5 \mathrm{R}$ is often used as a starting material in the manufacturing process of polymer dyes. ${ }^{8}$ In residual industrial wastewater, reactive dyes are highly toxic, characterized by a high 
chemical and biological oxygen demand, by high, suspended solids and strong, vivid colors. ${ }^{9}$ When RBV-5R enters the aquatic environment, not least because of its $\mathrm{Cu}^{2+}$ content, it can be toxic to aquatic life because it prevents photosynthesis by blocking the entry of light into deeper layers.

Table 1. Properties of the studied RBV-5R textile dye

\begin{tabular}{lc}
\hline Dye name & Remazol Brilliant Violet-5R (RBV-5R) \\
\hline Molecular formula & $\mathrm{C}_{20} \mathrm{H}_{16} \mathrm{~N}_{3} \mathrm{Na}_{3} \mathrm{O}_{15} \mathrm{~S}_{4}$ \\
Colour Index Number & 18097 \\
Molecular Weight & $735.58 \mathrm{~g} / \mathrm{mol}$ \\
Maximum absorption & $\lambda_{\max }=553 \mathrm{~nm}$ \\
Chemical structure &
\end{tabular}

The adsorption processes have been widely researched in the context of water pollution and several alternative biosorbents have been tested for efficacy. These biosorbents can be household or industrial wastes: orangeand banana peel ${ }^{10}$ tea/coffee filter ${ }^{11,12}$ grape-, potato- and apple peel ${ }^{13}$ dead and dried mushrooms ${ }^{14,15}$ sawdust, ${ }^{16}$ bentonite ${ }^{17-19}$ clay. ${ }^{20}$

Eggshells from household waste can also be used as an adsorbent. The eggshell is a porous, uneven, granular structure with high surface area. It contains approximately 17000 pores. $95-97 \%$ of the eggshell is made up of calcium carbonate $\left(\mathrm{CaCO}_{3}\right)$, calcite crystals and fewer organic materials such as proteins, fats and sugars. ${ }^{21,22}$ Eggshell as an adsorbent can be used to remove many organic and inorganic substances: heavy metals ${ }^{23,24}$ phenols, ${ }^{25}$ cyanide, $^{26}$ drug residues, ${ }^{27}$ dyes. ${ }^{28-30}$

The aim of this study is to investigate the removal of Remazol Brilliant Violet-5R dye from aqueous solutions using calcined chicken (Gallus Gallus domesticus) eggshell household waste as biosorbent. This study covers a niche by focusing more specifically on the elemental analysis of the biosorbent material before and after adsorption (with EDX, Raman and FTIR analyses), calculating the biosorbents' bioconcentration factor and studying the morphological changes of the adsorbent using SEM images. Calcined eggshell was also characterized by thermogravimetric, BET surface methods.

\section{Materials and Methods}

\section{1. Adsorbate}

The analytical grade dye, Remazol Brilliant Violet-5R, selected for the purposes of the adsorption experiments in the present study, was purchased from DyeStar Singapore Pte. Ltd. It was used without any purification.
The dye stock solution of $2 \mathrm{~g} / \mathrm{L}$ was prepared by dissolving the dye powder with deionized (MilliQ) water. During adsorption studies, stock solution was diluted to the needed concentration $(20,40,60,80,100 \mathrm{mg} / \mathrm{L})$.

\section{2. Adsorbent}

Chicken eggshell (Gallus Gallus domesticus) samples were collected from kitchen waste. In order to remove pollutants and impurity from its surface, they were repeatedly washed with tap water and ultrapure MilliQ deionized water. After drying (Memmert UN75PLUS dried at $85^{\circ} \mathrm{C}$ ) the chicken eggshell was crushed and shieved to $160 \mu \mathrm{m}$ particle size. Finally, it was calcined at $1000{ }^{\circ} \mathrm{C}$ for 4 hours.

$$
\mathrm{CaCO}_{3} \rightarrow \mathrm{CaO}+\mathrm{CO}_{2}
$$

\section{3. Batch Adsorption and Studies of Initial Parameters' Change}

The biosorption of azo-dye RBV-5R on the surface of calcined eggshell was carried out in $250 \mathrm{~mL}$ Berzelius flask using $100 \mathrm{~mL}$ dye in aqueous solution.

During batch equilibrium experiments, the concentration of the dye was measured by Agilent Cary 60 UVVIS spectrophotometer at $\lambda_{\max }=553 \mathrm{~nm}$. The concentration was calculated by using calibration curve quantitative measuring technique. Results listed below are the means and standard deviations from 9 different measurements.

To achieve maximum adsorption capacity and efficiency, various initial parameters (such as initial dye concentration, biomass weight, aqueous solution $\mathrm{pH}$ and temperature) affecting the RBV-5R dye removal process on calcined eggshell were studied and optimized.

The effect of initial dye concentration on adsorption with calcined eggshell (160 $\mu \mathrm{m}$ particle size) was studied using constantly rotating $(700 \mathrm{rpm}) 1.5 \mathrm{~g}$ calcined eggshell in a $100 \mathrm{~mL}$ aqueous solution of RBV-5R azo-dye between $20-100 \mathrm{mg} / \mathrm{L}$ concentrations at $20{ }^{\circ} \mathrm{C}$ without $\mathrm{pH}$ adjustment $(\mathrm{pH}=6)$.

To examine the effect of calcined eggshells weight, $100 \mathrm{~mL}$ volumes of $20 \mathrm{mg} / \mathrm{L}$ concentration RBV-5R dye $(\mathrm{pH}=6)$ was constantly $(700 \mathrm{rpm})$ mixed with $0.5-1-1.5-2$ g eggshell $(160 \mu \mathrm{m}$ particle size $)$ at $20^{\circ} \mathrm{C}$.

Due to the fact that dye adsorption is $\mathrm{pH}$ dependent, the effect of $\mathrm{pH}$ was also studied between $\mathrm{pH}=2-11$ by mixing $20 \mathrm{mg} / \mathrm{L}$ dye solution at $700 \mathrm{rpm}$ with $1.5 \mathrm{~g}$ calcined eggshell ( $160 \mu \mathrm{m}$ particle size $)$ at $20^{\circ} \mathrm{C}$. In each case $1 \mathrm{M} \mathrm{HCl}$ and $\mathrm{NaOH}$ was used as $\mathrm{pH}$ adjuster (Hanna HI4521 pH/mV/ISE/temperature Bench Meter with dual channel electrode). First, the dye solutions were prepared, then the Berzelius flask containing the solution was put on a magnetic stirrer, and the wished $\mathrm{pH}$ was adjusted with $1 \mathrm{M} \mathrm{NaOH}$ and $1 \mathrm{M} \mathrm{HCl}$. IKA C-MAG HS7 digital magnetic shakers were used to investigate the effect of temperature $\left(20,30,40^{\circ} \mathrm{C}\right)$ on the adsorption process, where con- 
stant parameters were: $\mathrm{c}=20 \mathrm{mg} / \mathrm{L}$, particle size $=160 \mu \mathrm{m}$, biomass weight $=1.5 \mathrm{~g}, 700 \mathrm{rpm}$ agitation speed, $\mathrm{pH}=6$.

\section{4. Analytical Methods}

For the characterization of calcined eggshell, thermal analysis was carried out using a DTA-TG differential heat analyzer, Model: STA 449 F5 Jupiter, Manufacturer: Netzsch GmbH, Germany, with graphite furnace, with a possibility of analysis of up to $1600^{\circ} \mathrm{C}$. The heat treatment temperature of the samples was $1200^{\circ} \mathrm{C}$ at a heating rate of $10 \mathrm{~K} / \mathrm{min}$ under a nitrogen atmosphere.

Total surface area $\left(S_{t}\right)$, pore volume $\left(V_{p}\right)$ and pore radius $\left(\mathrm{R}_{\mathrm{m}}\right)$ were obtained from $\mathrm{N}_{2}$ adsorption-desorption isotherms (measured at $-196{ }^{\circ} \mathrm{C}$ ), using the BET model for $\mathrm{S}_{t}$ determination, and Dollimore - Heal method for $V_{p}$ and $R_{m}$. The isotherms were recorded using Sorptomatic 1990 apparatus (Thermo Electron Corporation). For prior determination, the samples were degassed at $150{ }^{\circ} \mathrm{C}$ in vacuum (around $1 \mathrm{~Pa}$ ) for 3 hours, in order to remove the physically adsorbed impurities from the surface. No pressure variation was observed at the end of the 1 hour samples degassing process. ${ }^{31-33}$

The powdered calcined eggshell surface was studied by scanning electron microscopy (JEOL (USA) JSM 5510 LV SEM) at various magnifications before and after ad- sorption. During the test, eggshell particle sizes of $160 \mu \mathrm{m}$ were used (control, $2 \mathrm{~g} / \mathrm{L} \mathrm{RBV-5R}$ solution). To improve the quality of the images and to increase the electrical conductivity of the surface, the surface of the samples was covered with a thin layer $(10 \mathrm{~nm})$ of $1.33 \times 10^{-6} \mathrm{mBar}$ vacuum.

Scanning Jeol JEM $5510 \mathrm{JV}$ and Oxford Instruments EDS Analysis System Inca 300 (UK) were used to examine the elemental composition of the calcined eggshell on the control and the dye adsorbed samples (2 g/L RBV-5R). Elemental distribution was studied and enrichment factors were calculated. The value obtained gives the percentage of elements in the dye-, ,contaminated" sample relative to the control sample.

$$
\delta=\frac{\mathrm{R}_{\text {sample }}-\mathrm{R}_{\text {control }}}{\mathrm{R}_{\text {control }}} \cdot 100
$$

Where: $\delta$ - enrichment factor, $\mathrm{R}_{\text {sample }}$ - the EDX results for eggshells in the $2 \mathrm{~g} / \mathrm{L}$ solution, - the amount of elements in the control eggshell obtained during EDX measurement.

FTIR spectroscopy was used to identify the functional groups of calcined eggshells before and after RBV$5 \mathrm{R}$ dye adsorption, which was performed by JASCO 615FTIR at 500-4000 $\mathrm{cm}^{-1}$ wavelength.

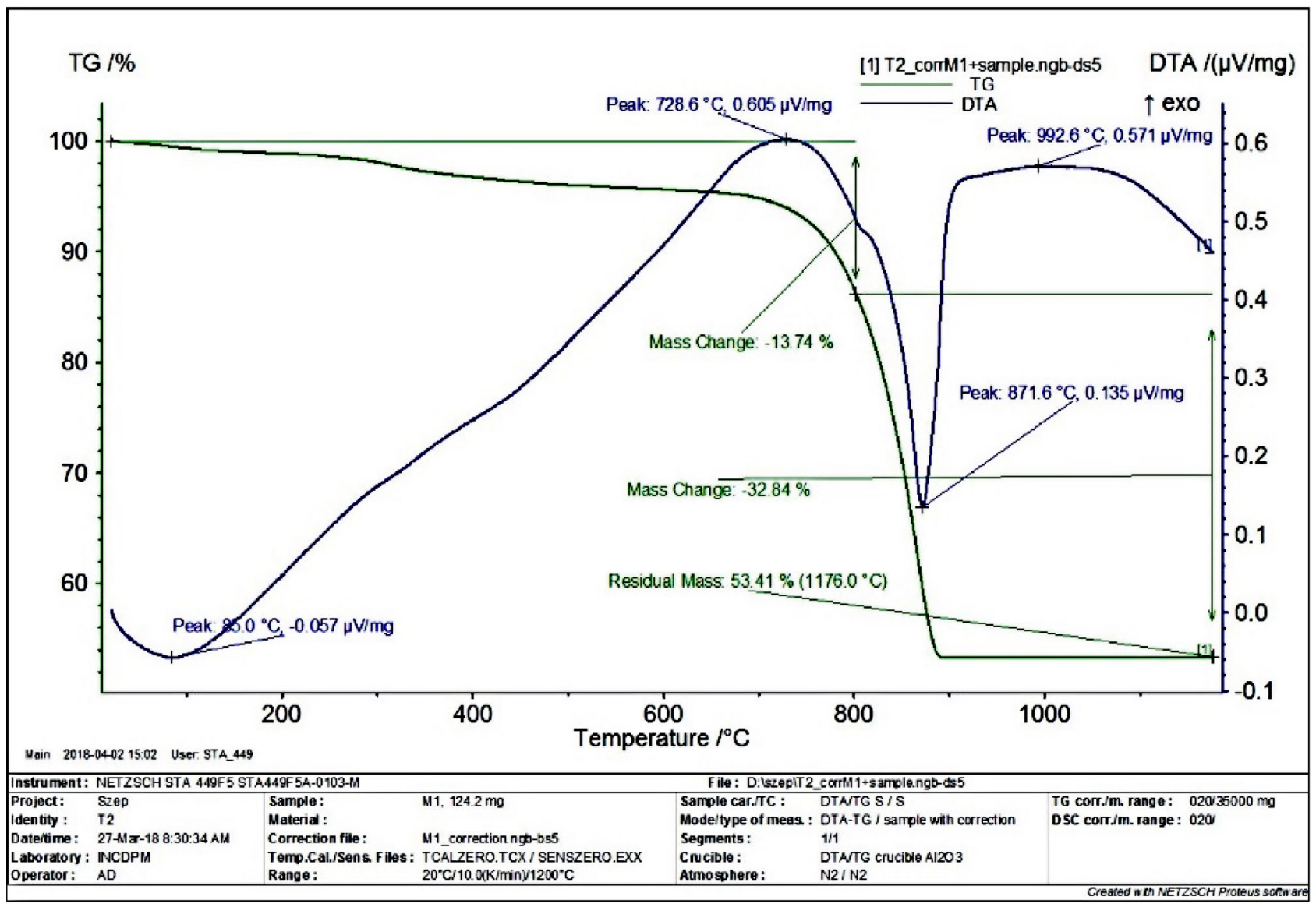

Figure 1. Thermogravimetric measurements (Created with NETZSCH Proteus software): TG - Thermogravimetry, DTA - Differential Thermoanalytics 
HORIBA JobinYvon LabRAM HR Raman Spectrophotometer, with a $532 \mathrm{~nm}$ wavelength green laser (with a laser point diameter of $1.5 \mu \mathrm{m}$, an optic lattice of 1800 lines/ $\mathrm{mm}$, and 100x objective) was used to study the material assays of calcined eggshell (powdered form), RBV-5R dye.

\section{Results and discussion}

\section{1. Thermogravimetry}

Materials can change their physical and chemical properties due to heat, and thermal analyses can be used to test these properties. During the process, the eggshell biosorbent properties were investigated as a function of elapsed time or temperature variation. The most important ingredient of eggshell is calcite with a known decomposition temperature of $900{ }^{\circ} \mathrm{C} .{ }^{31}$ But at this temperature we found gray/black residues in the sample. Figure 1 made with Proteus software shows the TG-thermogravimetric curve and the DTA differential thermal analysis curve (which gives the heat flow at the temperature).

Based on the TG curve (green curve), there are two main mass losses owing to temperature, below $800^{\circ} \mathrm{C}$ and in the range $800-900^{\circ} \mathrm{C}$. In the first case, mass loss can be explained with the disappearance of adsorbed water molecules and organic compounds. In the second case, the main weight loss corresponds to $32.84 \%$ by weight when the $\mathrm{CaCO}_{3}$ phase is transformed into a $\mathrm{CaO}$ phase.

Since the mass of the sample remained constant after $900{ }^{\circ} \mathrm{C}$, we can assume that the transformation is complete. $^{32,33}$

According to the DTA curve, decomposition occurs at $728.6^{\circ} \mathrm{C}$, which is the maximum temperature at which exothermic phenomenon or decomposition occurs.

\section{2. BET surface}

Based on the values obtained in the BET surface and Dollimore-Heal method, listed in Table 2, it can be observed that after the adsorption the surface area $\left(\mathrm{S}_{\mathrm{t}}\right)$ of the calcined eggshell decreased, thus dye molecules had become incorporated into the pores. Moreover, we can see that the pore volume $\left(\mathrm{V}_{\mathrm{p}}\right)$ also decreased after dye adsorption.

Table 2. Eggshell surface area and pore volume

\begin{tabular}{lcc}
\hline Sample & $\mathbf{S}_{\mathbf{t}}\left(\mathbf{m}^{2} / \mathbf{g}\right)$ & $\mathbf{V p ~}\left(\mathrm{cm}^{3} / \mathbf{g}\right)$ \\
\hline Control calcined eggshell & 3.0 & 0.015 \\
Dye adsorbed calcined eggshell & 1.7 & 0.012 \\
\hline
\end{tabular}

The size distribution of the pore bars of the two samples is shown in Figure 2. Figure 2.1 shows the multimodal mesoporous and macroporous structure of untreated calcined eggshell having three main ranges for the pore radi-
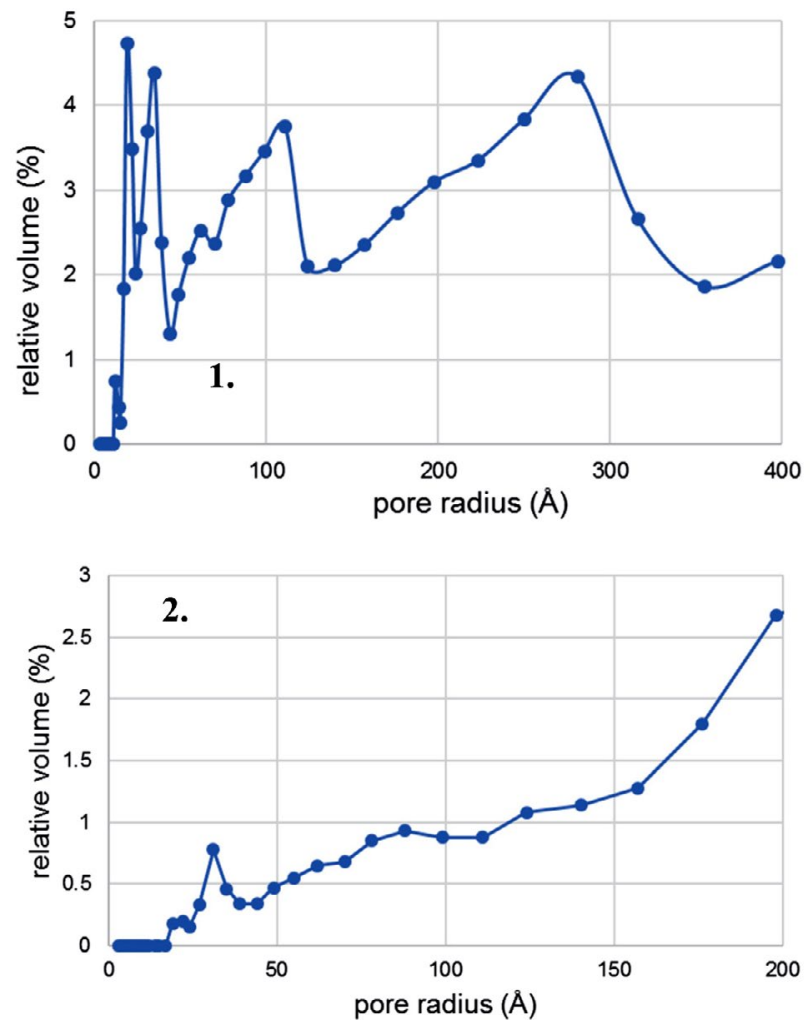

Figure 2. Pore size distribution (1) control (2) dye adsorbed calcined eggshell

us: $21-20 \AA, 110 \AA$ and $280 \AA$. The first two are located in the mesoporous region and the last one is in the small macroporous region.

As for the sample after the adsorption, due to the small value of the surface, the pore size analysis is not very accurate, but there are two types of pores with radius of about $30 \AA$ and $90 \AA$. For values above $150{ }^{\circ} \mathrm{C}$, the pore radius cannot be calculated due to the nitrogen condensation between the material particles.

\section{3. Effect of the Initial RBV-5R Dye Concentration}

Five different studies $\left(C_{i}=20-100 \mathrm{mg} / \mathrm{L}\right)$ were made for the adsorption process at a constant $700 \mathrm{rpm}$ at room temperature, $1.5 \mathrm{~g}$ of biomass $\left(1000{ }^{\circ} \mathrm{C}\right.$ calcined eggshell) without adjusting the $\mathrm{pH}$ of the aqueous medium. The equilibrium values obtained at the end of the adsorption were used to calculate the efficiency of the biosorption and the maximum amount of material in equilibrium. Figure 3 graphically illustrates the calculated values. Here we can observe that the efficiency achieved is in all cases greater than $90 \%$. Compared to our previous study (untreated eggshell adsorption), no clear trend was observed regarding the increase in concentration. But for subsequent comparison, studies were performed on the $20 \mathrm{mg} / \mathrm{L}$ solution. 


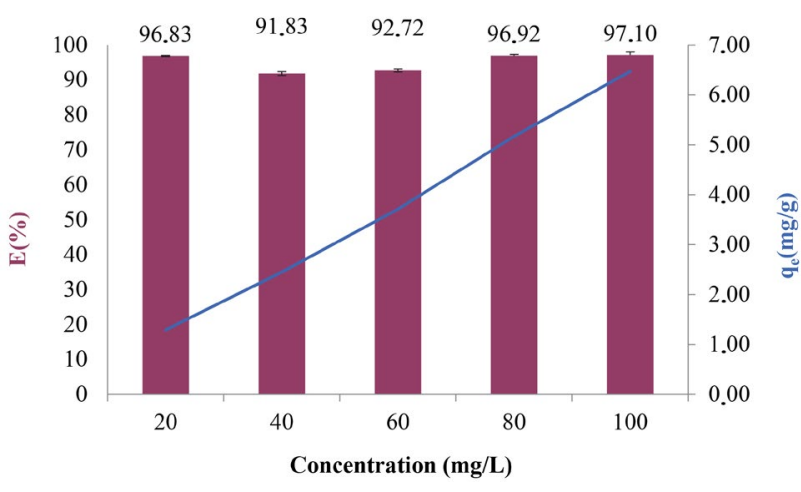

Figure 3. Effect of the initial RBV-5R dye concentration, standard deviations calculated from measurements from nine parallel results, where E-efficiency of adsorption, $\mathrm{q}_{\mathrm{e}}$-maximum adsorption capacities at equilibrium $\left(\mathrm{C}_{\mathrm{i}}=20-100 \mathrm{mg} / \mathrm{L}, 1.5 \mathrm{~g}\right.$ biomass, $160 \mu \mathrm{m}, 700$ rpm, $\left.\mathrm{pH}=6.0 \pm 0.2, \mathrm{~T}=20 \pm 1{ }^{\circ} \mathrm{C}\right)$.

\section{4. Effect of the Amount of Biosorbent}

The amount of biomass is an important factor in the adsorption process. In theory, the higher the amount of adsorbent present in the aqueous medium, the more binding sites are available to the dye molecules. Nonetheless, after a while, the binding dye molecules are depleted in the solution. In our research we investigated the adsorption parameters of four different initial amounts of calcined eggshells $(0.5 ; 1 ; 1.5 ; 2 \mathrm{~g})$.

We studied the dye's adsorption on untreated eggshell, it can be observed in Figure 4 that the increase as the amount of calcined eggshell increases, the removal efficiency increases, but the quantity in equilibrium exhibits a decreasing tendency. Based on the results, the highest efficiency was obtained $(\mathrm{E} \%=96.83)$ for $1.5 \mathrm{~g}$ of calcined eggshell.

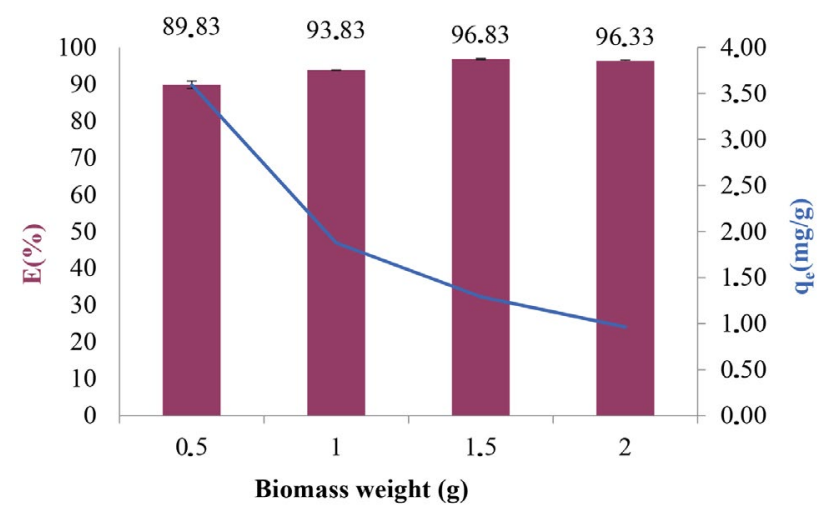

Figure 4. Effect of the initial biomass weight, standard deviations calculated from measurements from nine parallel results, where E-efficiency of adsorption, $\mathrm{q}_{\mathrm{e}}$-maximum adsorption capacities at equilibrium $\left(\mathrm{C}_{\mathrm{i}}=20 \mathrm{mg} / \mathrm{L}, 160 \mu \mathrm{m}, 700 \mathrm{rpm}, \mathrm{pH}=6.0 \pm 0.2, \mathrm{~T}=20\right.$ $\left.\pm 1^{\circ} \mathrm{C}\right)$.

\section{5. Effect of the $\mathrm{pH}$ of an Aqueous Medium}

The $\mathrm{pH}$ of the aqueous medium can influence the biosorption of the dyes: changes in sorbent properties, adsorption mechanism, dissociation of the dye molecules, and the chemical structure of the dye. Changing the $\mathrm{pH}$ may cause surface charge as well. Reactive dyes and thus RBV-5R dressing dyes are anionic in nature. This property implies that the dye may be adsorbed in acidic medium with greater efficiency. The $\mathrm{pH}$ of the prepared $20 \mathrm{mg} / \mathrm{L}$ dye solutions was adjusted using $1 \mathrm{M} \mathrm{NaOH}$ and $1 \mathrm{M} \mathrm{HCl}$ solutions. In practice, adding $\mathrm{HCl}$ to the aqueous solution protonates the surface of the biosorbent in the solution (acidic medium), so that the anionic dye is willing to bound to the surface of the adsorbent. In the basic medium, by adding $\mathrm{NaOH}$, there is a repulsive force between the dye and the adsorbent, so that the surface of the calcined eggshell is deprotonated; therefore, the adsorption is less efficient.

The calcined eggshell used in our research contains $\mathrm{CaO}$, which is alkaline, highly influencing the $\mathrm{pH}$ of the aqueous medium. At the end of the adsorption experiments, the solutions were filtered and the $\mathrm{pH}$ of the filtrate was checked. All solutions showed a $\mathrm{pH}$ of around 11. Figure 5 shows the results in equilibrium, the constant values of quantity in equilibrium and efficiency were the consequence of the similar $\mathrm{pH}$.

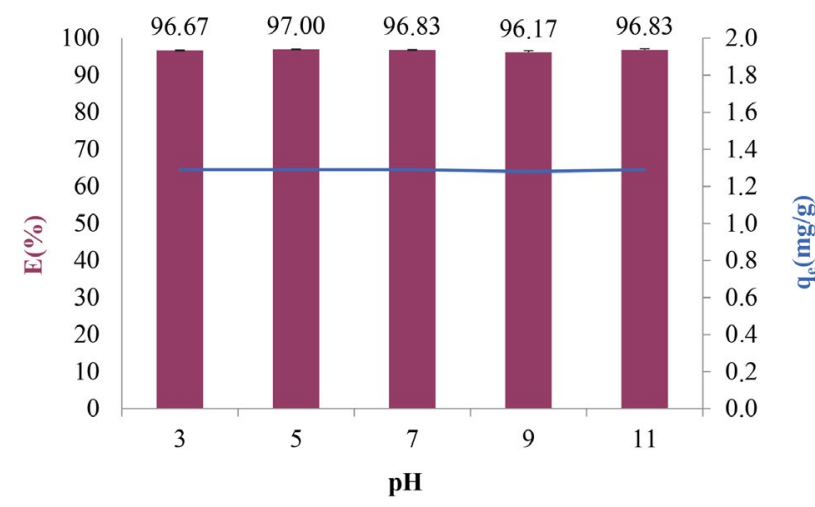

Figure 5. Effect of the $\mathrm{pH}$ of an aqueous medium, standard deviations calculated from measurements from nine parallel results, where E-efficiency of adsorption, $\mathrm{q}_{\mathrm{e}}$-maximum adsorption capacities at equilibrium $\left(\mathrm{C}_{\mathrm{i}}=20 \mathrm{mg} / \mathrm{L}, 1.5 \mathrm{~g}, 160 \mu \mathrm{m}, 700 \mathrm{rpm}, \mathrm{pH}=2-11\right.$, $\left.\mathrm{T}=20 \pm 1^{\circ} \mathrm{C}\right)$.

\section{6. Effect of Solution Temperature}

In our research, the adsorption properties of the calcined eggshell were studied by changing the temperatures $\left(20,30,40^{\circ} \mathrm{C}\right)$ of the dye solution.

Figure depicts the effect of temperature dependence on the efficiency and the quantity in equilibrium. It can be observed that the efficiency and the quantity in equilibrium decreases with the increase in the temperature of the aqueous medium. Similar results were obtained in our previous 
study for untreated eggshells, but with lower efficiency (20 $\left.{ }^{\circ} \mathrm{C}: 94.39,30^{\circ} \mathrm{C}: 92.36,40^{\circ} \mathrm{C}: 89.65\right)$. This was anticipated because the molecules' thermal movement increases with the increase of temperature, and thus adsorption decreases.

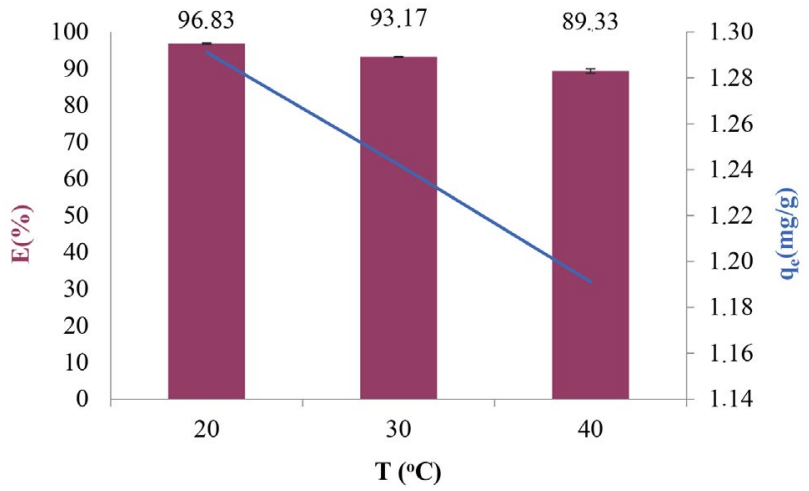

Figure 6. Effect of the temperature, standard deviations calculated from measurements from nine parallel results, where E-efficiency of adsorption, $\mathrm{q}_{\mathrm{e}}$-maximum adsorption capacities at equilibrium $\left(\mathrm{C}_{\mathrm{i}}=\right.$ $\left.20 \mathrm{mg} / \mathrm{L}, 1.5 \mathrm{~g}, 160 \mu \mathrm{m}, 700 \mathrm{rpm}, \mathrm{pH}=6.0 \pm 0.2, \mathrm{~T}=20-40 \pm 1{ }^{\circ} \mathrm{C}\right)$.

\section{7. Thermodynamics}

In our research we investigated the effect of temperature $(239 \mathrm{~K}, 303 \mathrm{~K}$ and $313 \mathrm{~K})$ on the adsorption process. Based on the results obtained, $\ln \left(\mathrm{q}_{\mathrm{e}} / \mathrm{C}_{\mathrm{e}}\right)$ was plotted against $1 / \mathrm{T}$, and the thermodynamic parameters were determined on the basis of the equation of the obtained straight line.

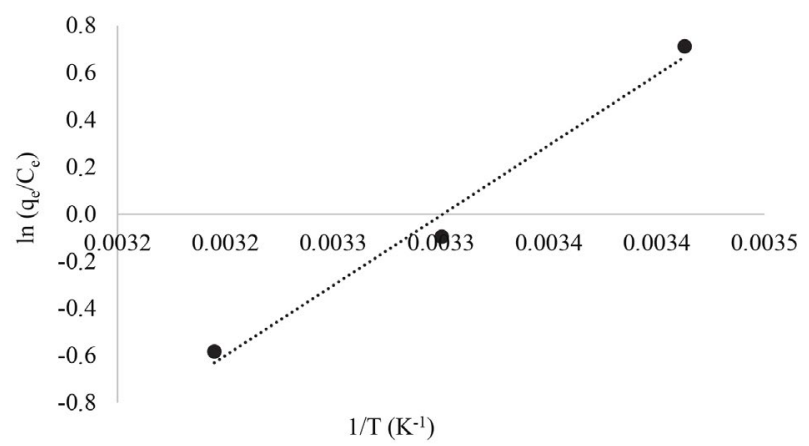

Figure 7. van't Hoff plot for the biosorption of RBV-5R dye, where slope $\left(-\Delta H^{\circ} / R\right)=5952$, intercept $\left(\Delta S^{\circ} / R\right)=-19.65$ and $R^{2}$-coefficient $=0.985$.

Table 3 shows the thermodynamic parameters calculated on the basis of equation, namely enthalpy, entropy and free energy of Gibbs. In line with the results of our untreated eggshell experiments, $\Delta \mathrm{H}$, enthalpy is less than $84 \mathrm{~kJ} / \mathrm{mol}$ but positive. According to literature data, it can be concluded that adsorption is an endothermic process and physical adsorption $(\Delta \mathrm{H}<84 \mathrm{KJ} /$ mole physical adsorption; $\Delta \mathrm{H} 84-420 \mathrm{~kJ} / \mathrm{mol}$ of chemical adsorption), and the positive value of $\Delta S$ entropy indicates the randomness of the adsorption process. Gibbs' free energy is reduced by the effect of temperature. The lower the temperature, the higher the spontaneity of the process, so it is inversely proportional. ${ }^{34-37}$

In summary, based on thermodynamic data, it can be said that biosorption is a spontaneous and endothermic process. Physical adsorption occurs between the dye molecules and the surface of the calcined eggshell.

Table 3. Calculated thermodynamic parameters

\begin{tabular}{lcccc}
\hline $\begin{array}{l}\Delta \mathrm{S} \\
(\mathrm{J} / \mathbf{m o l ~ K})\end{array}$ & $\begin{array}{c}\Delta \mathrm{H} \\
(\mathbf{k J} / \mathbf{m o l})\end{array}$ & $\mathbf{2 9 3} \mathbf{K}$ & $\begin{array}{c}\Delta \mathrm{G}(\mathbf{k J} / \mathbf{m o l}) \\
\mathbf{3 0 3}\end{array}$ & $\mathbf{3 1 3 \mathrm { K }}$ \\
\hline 0.2 & 49.6 & 1.8 & 0.2 & -1.5 \\
\hline
\end{tabular}

\section{8. Adsorption Isotherm Models}

In order to characterize the adsorption process, the four most frequently used isotherm models (Langmuir, Freundlich, Temkin, Dubinin-Radushkevich) were used. In each case, the linear regression coefficients and characteristic parameters were calculated based on equations received from linearized forms. ${ }^{24}$ The calculated parameters lead us to state that adsorption is physical in nature (Table 4). Weak van der Waals bonds are formed between the biosorbent and the dye, because the B-Temkin constant is less than 20 $\mathrm{kJ} / \mathrm{mol}$ and the E-energy is less than $8 \mathrm{~kJ} / \mathrm{mol}$. Since the correlation coefficient of the Langmuir isotherm is the highest in our experimental conditions, the Langmuir isotherm model describes the process, assuming that the adsorption is reversible, monolayer. The surface of the adsorbent, in this case calcined eggshell, has a homogeneous, uniform strength with a constant number of binding centers that incorporate only one molecule into a binding site.

\section{9. Adsorption Kinetic and Diffusion Models}

Kinetic and diffusion models can be used to study the adsorption mechanisms between biosorbent, calcined

Table 4. Parameters of isotherm models $\left(\mathrm{C}_{\mathrm{i}}=20-100 \mathrm{mg} / \mathrm{L}, 1.5 \mathrm{~g}\right.$ biomass, $\left.160 \mu \mathrm{m}, 700 \mathrm{rpm}, \mathrm{pH}=6.0 \pm 0.2, \mathrm{~T}=20 \pm 1{ }^{\circ} \mathrm{C}, \mathrm{P}=1 \mathrm{~atm}\right)$

\begin{tabular}{|c|c|c|c|c|c|c|c|c|c|c|c|}
\hline \multicolumn{3}{|c|}{ Langmuir } & \multicolumn{2}{|c|}{ Freundlich } & \multicolumn{3}{|c|}{ Dubinin-Radushkevich } & \multirow[b]{2}{*}{$\mathbf{R}^{2}$} & \multicolumn{3}{|c|}{ Temkin } \\
\hline $\begin{array}{l}\mathrm{K}_{\mathrm{L}} \\
(\mathrm{l} / \mathrm{mg})\end{array}$ & $\underset{(\mathrm{mg} / \mathrm{g})}{\mathrm{q}_{\max }}$ & $\mathbf{R}^{2}$ & $\mathbf{n}$ & $\underset{\left(\mathrm{mg}^{(1-1 / \mathrm{n})} \mathbf{l}^{1 / \mathrm{n}} / \mathrm{g}\right)}{\mathrm{K}_{\mathrm{f}}}$ & $\mathbf{R}^{2}$ & $\begin{array}{c}\beta \\
\left(\mathbf{m o l}^{2} \mathbf{k J}^{2}\right)\end{array}$ & $\begin{array}{c}\mathrm{E} \\
(\mathrm{kJ} / \mathrm{mol})\end{array}$ & & $\begin{array}{c}\mathrm{A}_{\mathrm{T}} \\
(\mathbf{l} / \mathbf{g})\end{array}$ & $\begin{array}{c}\text { B } \\
(\mathrm{J} / \mathrm{mol})\end{array}$ & $\mathbf{R}^{2}$ \\
\hline 0.133 & 16.949 & 0.924 & 1.388 & 2.31 & 0.678 & $2 \times 10^{-7}$ & 1.58 & 0.833 & 2.4 & $3 \times 10^{-5}$ & 0.282 \\
\hline
\end{tabular}


Table 5. Parameters of kinetic models $\left(C_{i}=20-100 \mathrm{mg} / \mathrm{L}, 1.5 \mathrm{~g}\right.$ biomass, $\left.160 \mu \mathrm{m}, 700 \mathrm{rpm}, \mathrm{pH}=6.0 \pm 0.2, \mathrm{~T}=20 \pm 1{ }^{\circ} \mathrm{C}, \mathrm{P}=1 \mathrm{~atm}\right)$

\begin{tabular}{|c|c|c|c|c|c|c|c|}
\hline \multicolumn{2}{|l|}{$R B V-5 R$} & \multicolumn{3}{|c|}{ I. order kinetic model } & \multicolumn{3}{|c|}{ II. order kinetic model } \\
\hline $\begin{array}{l}\mathrm{C} \\
(\mathrm{mg} / \mathrm{L})\end{array}$ & $\begin{array}{c}q_{e}(\exp ) \\
(\mathrm{mg} / \mathrm{g})\end{array}$ & $\begin{array}{c}\mathbf{k}_{1} \\
(1 / \mathrm{min})\end{array}$ & $\begin{array}{c}\mathrm{q}_{\mathrm{e}}(\mathrm{calc}) \\
(\mathrm{mg} / \mathrm{g})\end{array}$ & $\mathbf{R}^{2}$ & $\begin{array}{c}\mathbf{k}_{2} \\
(\mathrm{~g} / \mathrm{mg} \mathbf{g} \times \min )\end{array}$ & $\begin{array}{c}\mathrm{q}_{\mathrm{e}}(\mathrm{calc}) \\
(\mathrm{mg} / \mathrm{g})\end{array}$ & $\mathbf{R}^{2}$ \\
\hline 20 & 1.290 & 0.534 & 1.43 & 0.839 & 6.842 & 1.946 & 0.9999 \\
\hline 40 & 2.450 & 0.019 & 1.67 & 0.459 & 0.553 & 3.678 & 0.9997 \\
\hline 60 & 3.710 & 0.014 & 2.12 & 0.521 & 0.174 & 5.571 & 0.9997 \\
\hline 80 & 5.710 & 0.052 & 1.07 & 0.453 & 0.246 & 7.806 & 0.9999 \\
\hline 100 & 6.470 & 0.022 & 1.64 & 0.519 & 0.133 & 9.728 & 0.9999 \\
\hline
\end{tabular}

Table 6. Parameters of diffusion models $\left(\mathrm{C}_{\mathrm{i}}=20-100 \mathrm{mg} / \mathrm{L}, 1.5 \mathrm{~g}\right.$ biomass, $\left.160 \mu \mathrm{m}, 700 \mathrm{rpm}, \mathrm{pH}=6.0 \pm 0.2, \mathrm{~T}=20 \pm 1^{\circ} \mathrm{C}, \mathrm{P}=1 \mathrm{~atm}\right)$

\begin{tabular}{|c|c|c|c|c|c|c|c|}
\hline \multirow{2}{*}{$\begin{array}{l}R B V-5 R \\
\mathrm{C}(\mathrm{mg} / \mathrm{l})\end{array}$} & \multirow[b]{2}{*}{$\mathrm{D}\left(\mathrm{cm}^{2} / \mathrm{s}\right)$} & \multicolumn{3}{|c|}{ Intra-particle diffusion } & \multicolumn{3}{|c|}{ Liquid film diffusion } \\
\hline & & $k_{i p}\left(m g / g \cdot \min ^{1 / 2}\right)$ & Intercept & $\mathbf{R}^{2}{ }_{\text {ip }}$ & $k_{\mathrm{fd}}(1 / \min )$ & Intercept & $\mathbf{R}_{\text {fd }}^{2}$ \\
\hline 20 & $9.09 \times 10^{-8}$ & 0.060 & 1.088 & 0.746 & 0.399 & -2.08 & 0.841 \\
\hline 40 & $1.39 \times 10^{-8}$ & 0.012 & 2.287 & 0.218 & 0.018 & -2.86 & 0.666 \\
\hline 60 & $6.60 \times 10^{-9}$ & 0.028 & 3.326 & 0.334 & 0.001 & -2.59 & 0.508 \\
\hline 80 & $1.31 \times 10^{-8}$ & 0.151 & 3.776 & 0.375 & 0.059 & -2.31 & 0.819 \\
\hline 100 & $8.86 \times 10^{-9}$ & 0.169 & 4.579 & 0.418 & 0.019 & -2.19 & 0.506 \\
\hline
\end{tabular}

egg shells, and adsorbents, RBV-5R. The correlation coefficient of first order and second order kinetic models was determined by the linear regression method. The calculated parameters for each model are shown in Table 5. Since

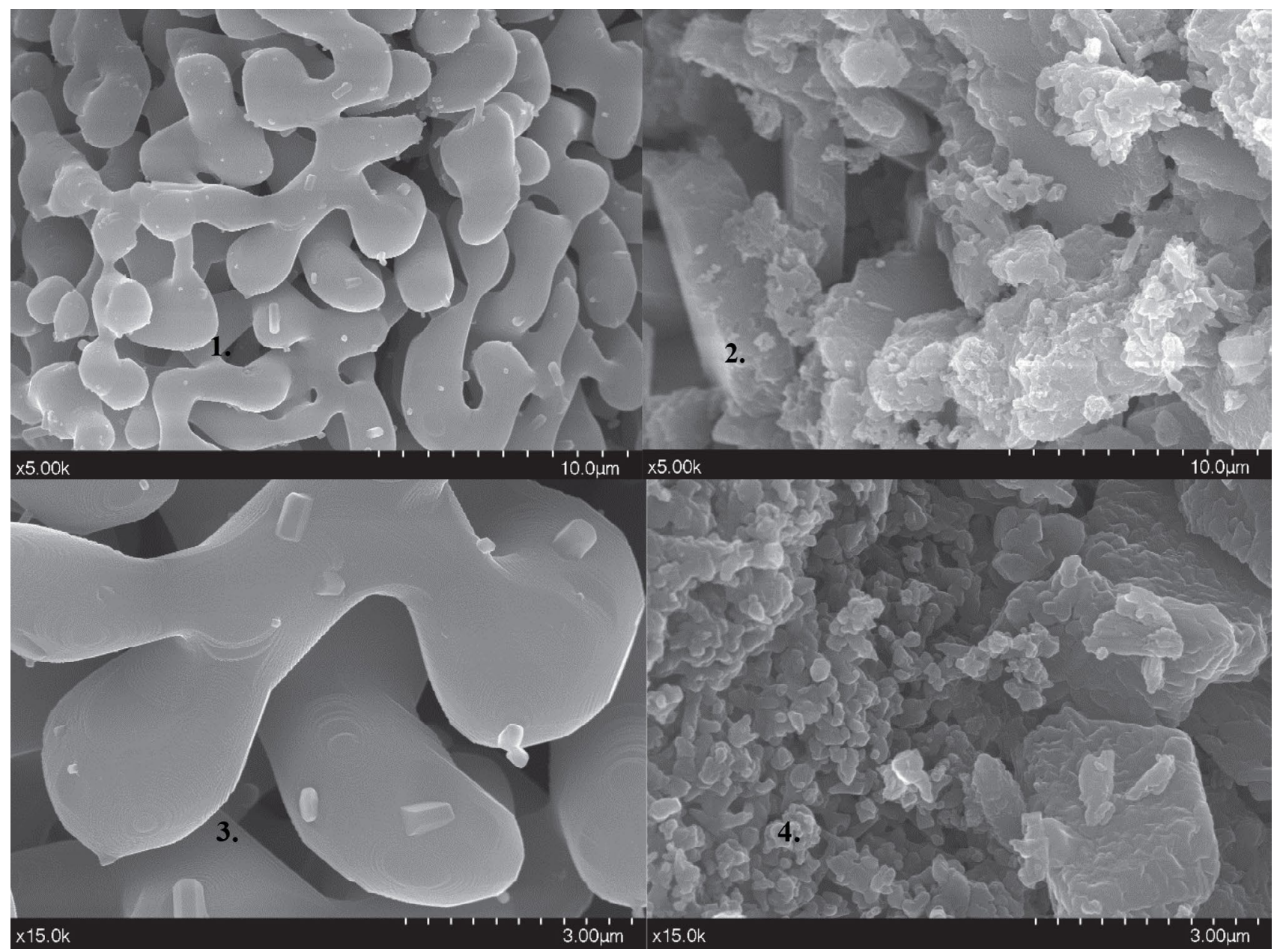

Figure 8. SEM $(1,3)$ control and $(2,4) 2$ g/L RBV-5R dye adsorbed calcined eggshell 
the calculations show that the linear regression coefficient is higher for the second order kinetic model, in addition to our experimental conditions, the adsorption process is described more precisely by the second order kinetic model developed by Ho and McKay. ${ }^{24,38}$

The intraparticular particle diffusion rate or the liquid film diffusion rate can control the biosorption of the $\mathrm{RBV}-5 \mathrm{R}$ clothing dye on the surface of the calcined eggshell.

Table 6 summarizes the calculated parameters for each diffusion model (intraparticular, liquid film), namely the linear regression coefficients, intersects, velocity values, and particle diffusion coefficient (D) The pore diffusion coefficients range from $6.60 \times 10^{-9}$ to $9.09 \times 10^{-8} \mathrm{~cm}^{2} / \mathrm{s}$ by varying the concentration. It can also be observed that none of the incisions pass through the origin of any diffusion model. It can be concluded that during the binding of the dye on the surface of the eggshell, the intra-particle section is not rate-determining, nor does the liquid film diffusion affect the adsorption process. ${ }^{34-37}$

In summary, the speed of the process is only determined by biosorption.

\section{10. Scanning Electron Microscopy}

The morphological properties and texture of the surface of the calcined eggshell used during the adsorption were studied by scanning electron microscopy, both for the control and the dye adsorbed eggshells. Figure 8 shows the captured images at $5000 \mathrm{x}$ and $15000 \mathrm{x}$ magnifications. In the figures (Figures 8.1 and 8.3), the porous structure of the calcined eggshell is observed between the irregular shaped structures. Moreover, on the surface some small crystals of about $300 \mathrm{~nm}$ can be found. Following the adsorption (Figures 8.2 and 8.4), this porous and irregular structure disappears, with the molecules of the dye filling the "gaps".

\section{11. Energy Dispersive Spectroscopy, Enrichment Factors}

To determine the elemental composition of calcined eggshell (control and dye adsorbed), energy-dispersive $\mathrm{X}$-ray spectroscopy was performed where the dye-adsorbed biomass was in a $2 \mathrm{~g} / \mathrm{L}$ solution. The table below shows (Table 7) that there were two main elements in the control sample, $\mathrm{Ca}$ and $\mathrm{O}$ - since calcined eggshells composition is $\mathrm{CaO}$ - and in small percentage $\mathrm{N}, \mathrm{Mg}, \mathrm{C}$, and $\mathrm{Pb}$. Gold was also present, but is not listed in the table because of its small value (it was attached to the specimen in vacuum to increase conductivity). After adsorption, the amount of $\mathrm{C}$ and the amount of $\mathrm{N}$ increased by more than $500 \%$, which is typically derived from the dye, being an azo dye.
Table 7. Results of EDX analyses

\begin{tabular}{lccc}
\hline Elements & $\begin{array}{c}\text { Wt(\%) calcined } \\
\text { eggshell }\end{array}$ & $\begin{array}{c}\text { Wt(\%)calcined } \\
\text { eggshell + RBV-5R }\end{array}$ & $\begin{array}{c}\text { Enrichment } \\
\text { factor (\%) }\end{array}$ \\
\hline C & 3.33 & 9.89 & 197.49 \\
N & 0.32 & 2.09 & 554.17 \\
O & 35.97 & 36.04 & 0.19 \\
Mg & 0.76 & 0.67 & -11.84 \\
Ca & 59.63 & 51.29 & -13.99 \\
\hline
\end{tabular}

\section{12 Fourier Transformation Infrared Spectroscopy}

Functional groups of calcined eggshell before and after adsorption were determined using Fourier transformations infrared spectroscopy in a wavelength range of 500 and $4000 \mathrm{~cm}^{-1}$ (Figure 9). Typical peaks of calcite and $\mathrm{CaO}$ are found at $874,1442,1795 \mathrm{~cm}^{-1}$ wavelengths, 713 and $1050 \mathrm{~cm}^{-1}$ typically exhibit peaks of $\mathrm{R}-\mathrm{SO}_{2}$, functional groups on 2923 and $2853 \mathrm{~cm}^{-1}$ represent $\mathrm{CH} .{ }^{21,38-40}$

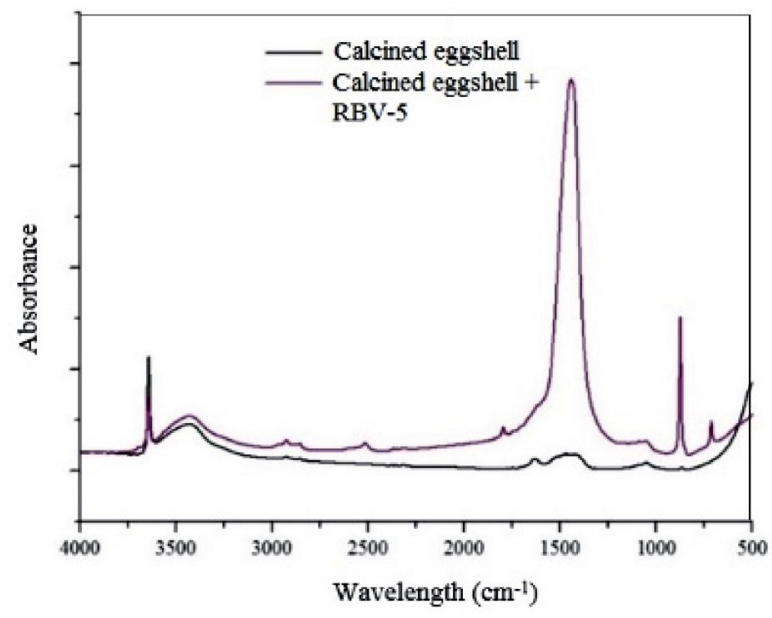

Figure 9. FTIR spectrum for control and $2 \mathrm{~g} / \mathrm{L}$ RBV-5R dye adsorbed calcined eggshell

\section{13. Raman Spectroscopy}

Raman spectroscopic measurements were performed in the Litosphere Fluidum Research Laboratory of the Eötvös Loránd University, Faculty of Science. Figure illustrates the spectra obtained in the Raman Shift interval between 100 and $1500 \mathrm{~cm}^{-1}$. The figure from top to bottom includes the calcined eggshell, RBV-5R dye adsorbed biomass and RBV-5R fabric dye spectra.

Spectrums of the control and the dye adsorbed calcined eggshells contained peaks of calcite described in literature ${ }^{41,42}$ at $150-154,712-711,1087-1086 \mathrm{~cm}^{-1}$. Peaks at $281-274$ and $3618 \mathrm{~cm}^{-1}$ represent $\mathrm{Ca}(\mathrm{OH})_{2}$. We also observe the characteristic peaks of the dye on the dye-adsorbed biomass sample: 582, 1261-1262, 1307-1306, 
1437-1435 $\mathrm{cm}^{-1}$. Newly emerging peaks may be suitable for aliphatic $\mathrm{C}-\mathrm{S}, \mathrm{N}=\mathrm{N}$ bonds. ${ }^{43}$

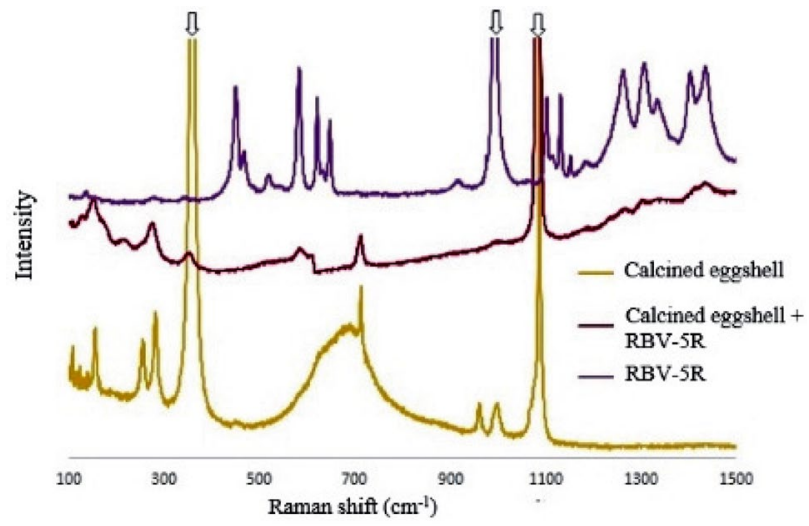

Figure 10. Raman spectrum for control, 2 g/L RBV-5R dye adsorbed calcined eggshell and RBV-5R dye

\section{14. Bioconcentration Factor}

Based on the equilibrium concentrations, the bioconcentration factor (BCF) was determined. It indicates how many times the calcined eggshell can accumulate the concentration of RBV-5R. BCF was calculated based on the concentration of the aqueous solution in equilibrium and the concentration of paint on the surface of the calcined eggshell. According to the work of Milinki, ${ }^{44}$ biosorbents can be grouped according to their bioconcentration value as: $\mathrm{BCF}>3$ large, $1.5<\mathrm{BCF}<3$ medium, $\mathrm{BCF}$ $<1.5$ small tendency. Five different concentrations (20$100 \mathrm{mg} / \mathrm{L}$ ) were determined for the BCF (Figure 11). The highest BCF value was obtained for the $100 \mathrm{mg} / \mathrm{L}$ solution where $\mathrm{BCF}=33.48$. It can be observed that the change in the BCF value shows a tendency similar to the efficiency of removing the initial dye concentration. Since the BCF has exceeded the value 3 for all concentrations, the calcined eggshell biomass has a high bioaccumulation tendency.

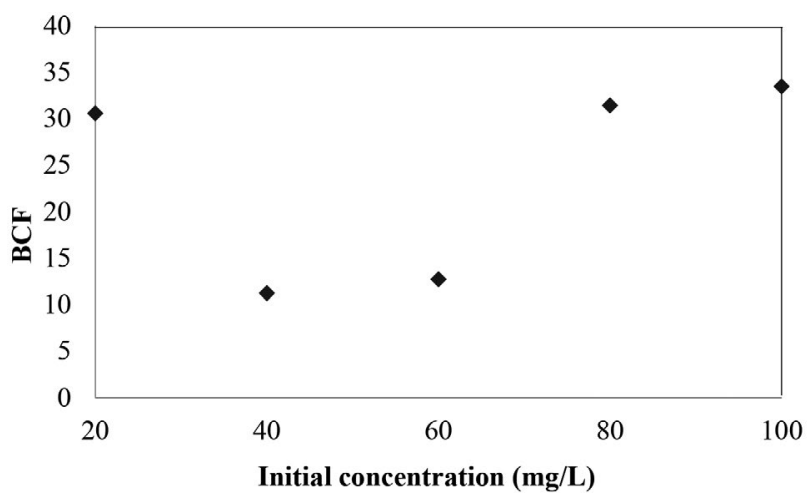

Figure 11. Bioconcentration factor

$\left(\mathrm{C}_{\mathrm{i}}=20-100 \mathrm{mg} / \mathrm{L}, 1.5 \mathrm{~g}\right.$ adsorbent, $160 \mu \mathrm{m}, 700 \mathrm{rpm}, \mathrm{pH}=6.0 \pm$ $\left.0.2, \mathrm{~T}=20 \pm 1{ }^{\circ} \mathrm{C}\right)$

\section{Conclusion}

This study proves that calcined is suitable for removing RBV-5R dye from sewage.

We have shown that the decomposition of the eggshell occurs at $728.6^{\circ} \mathrm{C}$. The total surface area of the eggshell decreased after the adsorption.

Changing the initial parameters leads to the following conclusions:

- by changing the initial dye concentration results show an efficiency higher than $90 \%$ in each case;

- as the amount of biomass increases, the amount of bound dye decreases; the highest efficiency is reached at $1.5 \mathrm{~g}(96.8 \%)$;

- in our case, the $\mathrm{pH}$ of the aqueous solution did not influence the potency of the binding because the sorbent used in it provided a strong alkaline $\mathrm{pH}(\mathrm{pH}=11)$; in each case the efficiency was higher than $95 \%$;

- the increase in the temperature of the aqueous solution reduces the efficiency of adsorption, the process is spontaneous, endothermic.

Mathematical modeling of equilibrium data leads to the following conclusions:

- in addition to our experimental conditions, the adsorption processes are most accurately described by the Langmuir isotherm;

- second order kinetic model characterizes the adsorption process;

- the results of the diffusion models prove that neither the intraparticular model nor the liquid film influences the rate of the adsorption process; only the adsorption is decisive;

- thermodynamic measurements further confirm the physical nature of adsorption, the spontaneity of the process, because as the temperature increases, the amount of adsorption decreased.

SEM images of calcined eggshell powder confirm that the dye molecules fill the porous structure. EDX measurements confirm the adsorption resulting in increased $\mathrm{C}$ and $\mathrm{N}$ and decreased $\mathrm{Ca}$ and $\mathrm{Mg}$. Based on the peaks of control and dye adsorbed samples of FTIR and Raman spectra, functional groups and bonds specific to each component can be found.

\section{Acknowledgements}

This work was funded by the Sapientia Hungariae Foundations' Collegium Talentum scholarship program. Research would not have been possible without support from the Research and Instrument Core Facility (RICF) of the Faculty of Science of the Eötvös University, Budapest (Dr. Csaba Szabó, László Aradi).

\section{References}

1. P. Juuti, T. Katko, H. Vuorinen, 'Environmental History of Water - Global view on community water supply and sanitation', 2007. 
2. C. Pregun, C. Juhász, 'Vízminőségvédelem', Debreceni Egyetem Agrár- És Gazdálkodástudományok Centruma (AGTC) Mezőgazdaság-, Élelmiszertudományi És Környezetgazdálkodási Kar Víz- És Környezetgazdálkodási Intézet.

3. TörökS., 'Vízellátás és szennyvízkezelés|Digitális Tankönyvtár', Szent István Egyetem, 2011.

4. Day Zero, http://coct.co/water-dashboard/, accessed April 2, 2018.

5. M. Kimmelman, N. Y. Times 2017.

6. Why Cape Town Is Running Out of Water, and Who's Next, https://news.nationalgeographic.com/2018/02/cape-town-running-out-of-water-drought-taps-shutoff-other-cities/, accessed March 30, 2018.

7. S. K. Chinta, S. Vijaykumar, I.J.E.M.S. 2013, 4, 308.

8. O. S. Bello, T. T. Siang, M. A. Ahmad, Asia-Pac. J. Chem. Eng. 2012, 7, 378. DOI:10.1002/apj.557

9. H. Zollinger, 'Color Chemistry: Syntheses, Properties, and Applications of Organic Dyes and Pigments', John Wiley \& Sons, 2003.

10. G. Annadural, R. S. Juang, D. J. Lee, Water Sci. Technol. J. Int. Assoc. Water Pollut. Res. 2003, 47, 185.

DOI:10.2166/wst.2003.0049

11. M. Hirata, N. Kawasaki, T. Nakamura, K. Matsumoto, M. Kabayama, T. Tamura, S. Tanada, J. Colloid Interface Sci. 2002, 254, 17. DOI: $10.1006 /$ jcis. 2002.8570

12. M. T. Uddin, M. A. Islam, S. Mahmud, M. Rukanuzzaman, J. Hazard. Mater. 2009, 164, 53.

DOI:10.1016/j.jhazmat.2008.07.131

13. F. Kaymak-Ertekin, A. Gedik, LWT - Food Sci. Technol. 2004, 37, 429. DOI:10.1016/j.lwt.2003.10.012

14. C. Majdik, S. Burca, A. Maicaneanu, M. Stanca, S. Tonk, P. Mezey, Rev. Roum. Chim. 2010, 55, 871.

15. B. Nagy, A. Măicăneanu, C. Indolean, C. Mânzatu, L. Silaghi-Dumitrescu, C. Majdik, J. Taiwan Inst. Chem. Eng. 2014, 45, 921. DOI:10.1016/j.jtice.2013.08.013

16. B. Nagy, A. Maicaneanu, C. Indolean, S. Burca, L. Silaghi-Dumitrescu, C. Majdik, Acta Chim. Slov. 2013, 60, 263.

17. R. Fabryanty, C. Valencia, F. E. Soetaredjo, J. N. Putro, S. P. Santoso, A. Kurniawan, Y.-H. Ju, S. Ismadji, J. Environ. Chem. Eng. 2017, 5, 5677. DOI:10.1016/j.jece.2017.10.057

18. N. Georgieva, Z. Yaneva, D. Dermendzhieva, Water Sci. Technol. 2017, 76, 1065. DOI:10.2166/wst.2017.283

19. Z. Huang, Y. Li, W. Chen, J. Shi, N. Zhang, X. Wang, Z. Li, L. Gao, Y. Zhang, Mater. Chem. Phys. 2017, 202, 266. DOI:10.1016/j.matchemphys.2017.09.028

20. A. Kausar, M. Iqbal, A. Javed, K. Aftab, Z.-H. Nazli, H. N. Bhatti, S. Nouren, J. Mol. Liq. 2018, 256, 395.

DOI:10.1016/j.molliq.2018.02.034

21. R. Slimani, I. El Ouahabi, F. Abidi, M. El Haddad, A. Regti, M. R. Laamari, S. E. Antri, S. Lazar, J. Taiwan Inst. Chem. Eng. 2014, 45, 1578. DOI:10.1016/j.jtice.2013.10.009

22. P. S. Guru, S. Dash, Adv. Colloid Interface Sci. 2014, 209, 49 DOI:10.1016/j.cis.2013.12.013

23. J. V. Flores-Cano, R. Leyva-Ramos, J. Mendoza-Barron, R. M. Guerrero-Coronado, A. Aragón-Piña, G. J. Labrada-Delgado, Appl. Surf. Sci. 2013, 276, 682.

DOI:10.1016/j.apsusc.2013.03.153
24. S. Tonk, C. Majdik, S. Robert, M. Suciu, E. Rápó, B. Nagy, A. Gabriela Niculae, Rev. Chim. -Buchar.- Orig. Ed.- 2017, 68, 1951.

25. L. Giraldo, J. C. Moreno-Piraján, J. Anal. Appl. Pyrolysis 2014, 106, 41. DOI:10.1016/j.jaap.2013.12.007

26. O. A. A. Eletta, O. A. Ajayi, O. O. Ogunleye, I. C. Akpan, J. Environ. Chem. Eng. 2016, 4, 1367.

DOI:10.1016/j.jece.2016.01.020

27. J. Li, D. H. L. Ng, R. Ma, M. Zuo, P. Song, Chem. Eng. Res. Des. 2017, 126, 123. DOI:10.1016/j.cherd.2017.07.005

28. N. Pramanpol, N. Nitayapat, Kasetsart J. - Nat. Sci. 2006, 40, 192.

29. A. Mittal, M. Teotia, R. K. Soni, J. Mittal, J. Mol. Liq. 2016, 223, 376. DOI:10.1016/j.molliq.2016.08.065

30. E. Rápó, R. Szép, Á. Keresztesi, M. Suciu, S. Tonk, Acta Chim. Slov. 2018, 65, 709. DOI:10.17344/acsi.2018.4401

31. Y.-B. Wang, J.-M. Jehng, Chem. Eng. J. 2011, 175, 548. DOI:10.1016/j.cej.2011.09.126

32. Nuchnapa Tangboriboon, Ruksapong Kunanuruksapong, A. Srivat, J. Ceram. Process. Res. 2012, Journal of Ceramic Processing Research 13(4):413-419, 413.

33. G. RAMESH, D. JAYABALAKRISHNAN, C. RAMESHKUMAR, J. Optoelectron. Biomed. Mater. 2018, 10, 21.

34. R. Mohadi, K. Anggraini, F. Riyanti, A. Lesbani, Sriwij. J. Environ. 2016, 1, 32. DOI:10.22135/sje.2016.1.2.32-35

35. H. J. Park, S. W. Jeong, J. K. Yang, B. G. Kim, S. M. Lee, J. Environ. Sci. 2007, 19, 1436.

DOI:10.1016/S1001-0742(07)60234-4

36. T. Witoon, Ceram. Int. 2011, 37, 3291. DOI:10.1016/j.ceramint.2011.05.125

37. O. S. Bello, M. A. Ahmad, Chem. Ecol. 2011, 27, 481. DOI:10.1080/02757540.2011.600696

38. H. Patel, Fresenius Environ. Bull. 2011, 20.

39. P. C. N. Ejikeme, E. M. Ejikeme, G. N. Okonkwo, Int. J. Tech. Res. Appl. 2014, 2, 96.

40. Subramani S.E., Thinakaran N., Process Saf. Environ. Prot. 2017, 106. DOI:10.1016/j.psep.2016.11.024

41. Y. S. Ho, G. McKay, Process Biochem. 1999, 34, 451. DOI:10.1016/S0032-9592(98)00112-5

42. B. P. Vinayan, Z. Zhao-Karger, T. Diemant, V. S. Kiran Chakravadhanula, N. I. Schwarzburger, M. Ali Cambaz, R. Jürgen Behm, C. Kübel, M. Fichtner, Nanoscale 2016, 8, 3296. DOI:10.1039/C5NR04383B

43. G. A. C. Ribeiro, D. S. A. Silva, C. C. dos Santos, A. P. Vieira, C. W. B. Bezerra, A. A. Tanaka, S. A. A. Santana, G. A. C. Ribeiro, D. S. A. Silva, C. C. dos Santos, A. P. Vieira, C. W. B. Bezerra, A. A. Tanaka, S. A. A. Santana, Polímeros 2017, 27, 16. DOI:10.1590/0104-1428.2386

44. A. V. Borhade, A. S. Kale, Appl. Water Sci. 2017, 1. DOI:10.1007/s13201-017-0558-9

45. S. K. Sharma, Spectrochim. Acta. A. Mol. Biomol. Spectrosc. 2007, 68, 1008. DOI:10.1016/j.saa.2007.06.047

46. D. B. Thomas, M. E. Hauber, D. Hanley, G. I. N. Waterhouse, S. Fraser, K. C. Gordon, J. Exp. Biol. 2015, 218, 2670. DOI:10.1242/jeb.124917

47. Raman Spectroscopy for Analysis and Monitoring, http:// www.horiba.com/fileadmin/uploads/Scientific/Documents/ Raman/bands.pdf. 
48. Ecotoxicology and Enviromental Protection|Digitális Tankönyvtár, http://www.tankonyvtar.hu/hu/tartalom/tamop412A/2011-0038_28_milinki_en/ix01.html, accessed November 26, 2017.

\section{Povzetek}

Onesnaženje vode je postalo z razvojem industrije pereč problem, zato je še bolj pomembno zagotavljanje vode ustrezne čistosti v zadostnih količinah. Po literaturnih podatkih je za tiskanje, živila in tekstilno industrijo uporabljano 100000 različnih barvil. Remazol briljantno vijolično -5R (RBV-5R ) spada v skupino azo barvil uporabljanih v tekstilni industriji. Namen raziskave je bil preučitev odstranjevanja anionskega barvila RBV-5R s kalciniranimi jajčnimi lupinami. Preučili smo vpliv začetne koncentracije barvila (20-100 mg/L RBV-5R), količine biomase, kontaktnega časa, temperature in $\mathrm{pH}$ vrednosti na proces adsorpcije. Določili smo ravnotežno adsorbirano količino barvila in učinkovitost procesa. Pri tem smo uporabili različne tehnike za določanje morfologije adsorbenta (EDX, SEM, FTIR, Raman), različne adsorpcijske modele za opis adsorpcijske izoterme (Langmuir, Freundlich, Temkin in Dubinin-Radushkevich) ter kinetične in difuzijske matematične modele za karakterizacijo procesa. Prav tako smo kalcinirane jajčne lupine okarakterizirali gravimetrično in z BET. Na osnovi rezultatov lahko zaključimo, da kalcinirane jajčne lupine učinkovito odstranjujejo barvilo iz vodnih raztopin.

Except when otherwise noted, articles in this journal are published under the terms and conditions of the Creative Commons Attribution 4.0 International License 